\title{
PERANCANGAN APLIKASI REMAJA MASJID DALAM MENDUKUNG PENINGKATAN AKTIFITAS DAN KEMAMPUAN MENGENAL ILMU AGAMA
}

\author{
Tri Sagirani ${ }^{1)}$, Rahayu Arya Shintawati ${ }^{2)}$, Puspita Kartikasari ${ }^{3)}$ \\ ${ }^{1}$ Fakultas Teknologi dan Informatika, Universitas Dinamika \\ ${ }^{2}$ Fakultas Ekonomi dan Bisnis, Universitas Dinamika \\ ${ }^{3}$ Fakultas Sains dan Matematika, Universitas Diponegoro \\ Email:Itris@dinamika.ac.id, 2puspitakartikasari@live.undip.ac.id
}

\begin{abstract}
Abstrak
Remaja masjid merupakan organisasi yang lahir dari sebuah lembaga pengelola masjid yang memiliki peran signifikan dalam mengatasi problematika keumatan, terutama problematika di generasinya yaitu remaja. Hadirnya organisasi Remaja Masjid menjadi harapan tersendiri di tengah masyarakat yang sibuk dengan urusan duniawi. Melalui aktifitas remaja masjid peran serta dalam mendidikkan informal terkhusus pada penanaman nilai-nilai keagamaan dapat diberdayakan. Penelitian ini mencoba memberikan solusi positif dengan memanfaatkan perkembangan teknologi informasi. Solusi yang ditawarka dalam program kemitraan masyarakat ini dicapai dengan melakukan perancangan aplikasi pembelajaran remaja masjid berbasis website yang diharapkan mampu mendorong dan membantu proses pendidikan keagamaan bagi anggota remaja masjid melalui aktifitas pembelajaran harian. Metode pengembangan dan pelaksanaan kegiatan ini meliputi communication, planning, modelling, contruction dan deployment. Pemanfaatan aplikasi pembelajaran untuk remaja masjid ini mampu memberikan kemudahan bagi pemateri untuk menyampaikan materi kajian dan dakwah, bagi pengurus remaja masjid, aplikasi ini mampu memberikan kesempatan penyebaran materi dan juga lakukan evaluasi terkait ketuntasan proses belajar dalam periode waktu tertentu dan bagi anggota remaja masjid sendiri, aplikasi ini mampu memberikan peningkatan kemampuan/wawasan dan keilmuan tentang Agama Islam.
\end{abstract}

Keywords: remaja masjid, pendidikan agama

\begin{abstract}
Mosque Youth Organization is an organization born from a management which has a siginificant role in overcoming peoplehood, especially the prolblem arises in mosque youth. The presence of Mosque Youth Organization becomes into a self expectation among people who are busy in world affairs. Through the mosque youth activities, the role of Mosque youth in educating adolescent informally, especially in empowering the value of religious matters. This study has tried to provide a positive solution by utilizing the development of Information Technology. This solution can be achieved by designing a website-based Mosque Youth Learning Application which is expected to be able to encourage and assist the process of religious education for the member of Mosque Youth Organization through daily learning activities. The methode used in developing and implementing these activities are holding a communication, planning, modelling, making a contruction and
\end{abstract}


deployment. The use of learning applications for Mosque Youth is able to provide easiness for presenter to deliver the materials and da'wah, for Mosque Youth administrators. This application is able to provide opportunities for dissemination of materials and also conduct the evaluations related to the completeness of the learning process in a certain period of time. It can also make the Mosque youth improve their insights and knowledge about Islam.

Keywords: Mousque Youth organization, religious education

\section{PENDAHULUAN}

Remaja adalah periode transisi perkembangan antara masa kanak-kanak dengan masa dewasa, yang melibatkan perubahan biologis, kognitif, dan sosioemosional dan dimasa inilah akan dialami perkembangan diri pada semua aspek/fungsi untuk memasuki masa dewasa (M. Ali dan M. Asrori, 2012). Tugas pokok remaja adalah mempersiapkan diri memasuki masa dewasa (Larson dkk, 2002 dalam Santrock, 2007) Banyak aktifitas yang dapat diikuti oleh remaja untuk melewati masa pertumbuhannya dan melatih diri untuk dapat berinteraksi sosial dengan lingkungan. Interaksi sosial merupakan hubungan dinamis yang menyangkut hubungan antara perorangan, antar kelompok, maupun antar perorangan dengan kelompok. Interaksi sosial adalah suatu hubungan antara dua atau lebih individu, dimana perilaku individu yang satu mempengaruhi, mengubah atau memperbaiki perilaku individu yang lain atau sebaliknya (Danny Haryanto dan G. Edwi Nugroho, 2011).

Untuk menjawab tantangan kedepan bagi remaja, maka dibutuhkan sebuah wadah atau komunitas salah satunya adalah aktifitas dibidang keagamaan yang sering kita kenal dengan istilah remaja masjid.

Remaja masjid merupakan organisasi yang lahir dari sebuah lembaga pengelola masjid yang memiliki peran signifikan dalam mengatasi problematika keumatan, terutama problematika di generasinya yaitu remaja. Generasi muda (remaja) sering kali menghadapi problematika seperti tawuran, penyalahgunaan narkoba, saling menghina di media sosial dan berbagai bentuk kenakalan khas remaja. Peran pengawasan orangtua yang melemah dan diikuti dengan rendahnya penanaman nilai-nilai keagamaan sering kali turut menjadi pemicu kenakalan tersebut. Remaja masjid perlu mendapat perhatian dari banyak pihak. Keberadaannya harus mendapatkan pengakuan dan bimbingan supaya remaja turut berperan dalam menangkis perilaku-perilikau negatif yang dekat dengan kehidupannya. Remaja perlu didorong melakukan berbagai kegiatan yang menghadirkan dampak postif, baik yang bersifat keagamaan maupun sosialkemasyarakatan. Hadirnya organisasi Remaja Masjid menjadi harapan tersendiri di tengah masyarakat yang sibuk dengan urusan duniawi. Melalui aktifitas remaja masjid peran serta dalam mendidikkan informal terkhusus pada penanaman nilai-nilai keagamaan dapat diberdayakan. Harapannya pegangan nilai-nilai keagamaan yang kuat dapat dimiliki oleh remaja dengan lebih baik lagi.

Kendalanya adalah remaja masjid sering kali kurang dikenal di kalangan masyarakat dan kurang diminati oleh para remaja muslim. Disisi lain hal ini membuat organisasi remaja masjid yang telah ada menjadi kurang percaya diri karena menganggap peran mereka sebagai pelengkap semata dalam masyarakat. 
Remaja masjid hanya terlihat menjalankan aktifitas dan kegiatan pada perayaan/ acara hari besar Islam, seperti pada hari raya. Sementara sehari-hari biasa peran mereka yang bersifat sosial dan kepemudaan seolah lenyap.

Dengan berkembangnya jaman yang syarat dengan majunya pemanfaatan teknologi informasi, remaja masjid dapat dengan mudah mengakses informasi yang kadang tidak bermanfaat. Mereka tidak lagi mengenal batas. Mereka menjadi asyik dengan dunianya, yang jauh namun sering mengabaikan masyarakat di sekitarnya. Keadaan seperti ini apabila dibiarkan dapat mendatangkan masalah pada perkembangan organisasi remaja khususnya remaja masjid.

Dari permasalahan yang ada pada pengelolaan remaja masjid inilah, kemudian Penelitian ini mencoba memberikan solusi positif untuk berperan serta aktif dalam proses pendidikan keagamaan bagi anggota remaja masjid melalui aktifitas pembelajaran harian bagi anggota remaja masjid dengan memanfaatkan keberadaan teknologi informasi. Dengan belajar setiap hari dengan memanfaatkan sebuah aplikasi online harapannya remaja masjid dapat menjadi solusi mengatasi kegalauan remaja yang masih mencari jati diri. Lewat pembinaan yang intensif dengan menanamkan nilai-nilai keislaman, serta dukungan dari berbagai pihak, remaja masjid kiranya mampu menjadi tempat atau wadah yang bisa menyalurkan gairah remaja kepada jalur yang lebih baik. Remaja masjid lebih mengenal Agama Islam, mengetahui dengan benar ajaran dan nilainilai kebaikan yang diajarkan dalam Islam dan pada akhirnya permasalahanpermasalahan remaja dilingkungan masyarakat dapat diminimalisir.

\section{METODE PELAKSANAAN}

Pembelajaran harian bagi anggota remaja masjid dengan memanfaatkan keberadaan teknologi informasi kiranya mampu menjadi salah satu solusi. Penyusunan media pembelajaran yang digunakan untuk mendukung aktifitas remaja masjid melakukan pembelajaran harian ini dibangun berbasis website, dengan focus pada website yang dinamis dan interaktif. Website dinamis merupakan suatu website yang secara strukturnya diperuntukan untuk dapat melakukan update sesering mungkin, sedangkan website Interaktif adalah suatu website yang didalamnya terjadi interaksi antara antara penggunanya. Metode pengembangan dan pelaksanaan kegiatan ini meliputi communication, planning, modelling, contruction dan Deployment (Pressman, 2015). Tahapan dalam penelitian ini dapat dilihat pada Gambar 1 berikut ini.

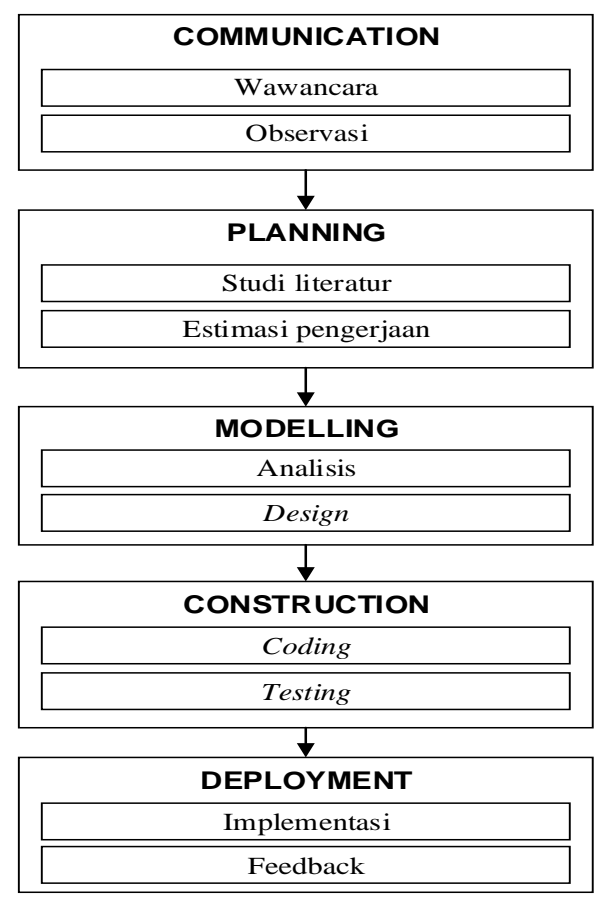

Gambar 1 Tahapan yang ditempuh 


\section{Communication}

Tahapan awal pada pengembangan perangkat lunak ini yaitu berfokus pada proses pengumpulan informasi dari masingmasing pihak yang terlibat (stakeholder). Pengumpulan data dilakukan melalui wawancara dan observasi. Tahapan ini berhasil mencatat adanya 3 kelompok pengguna yang terlibat, yaitu anggota remaja masjid, Pembina dalam hal ini tim pengajar/ pendakwah dan administrator yang dijalankan oleh pengurus organisasi.

\section{Planning}

Pada tahapan planning akan dilakukan proses studi literatur yang dilakukan untuk mencari solusi terkait hasil wawancara dan observasi dan membuat jobdesk mengenai aktivitas-aktivitas yang dilakukan dalam mencapai tujuan penelitian ini. Aktivitas yang dimaksud adalah estimating (estimasi waktu), scheduling (penjadwalan), dan tracking (penjabaran tugas) sehingga dapat dihasilkan roadmap yang dapat dijadikan panduan dalam aktivitas pengembangan. Pada aktifitas ini peneliti melakukannya dengan bantuan aplikasi trello.

\section{Modelling}

Pada tahapan ini dilakukan dua aktivitas yaitu analisis dan desain dimana kedua aktivitas tersebut dilakukan pada komponen-komponen dalam membangun aplikasi sesuai kebutuhan fungsional. Proses analisis menjadi langkah awal sebelum dilakukannya proses desain dalam merencanakan model sistem.

\section{Construction}

Tahapan Construction ini dilakukan dengan penerjemahan bentuk desain menjadi kode atau bentuk/bahasa yang dapat dibaca oleh mesin. Setelah pengkodean selesai, dilakukan pengujian terhadap sistem dan juga kode yang sudah dibuat. Tujuannya untuk menemukan kesalahan yang mungkin terjadi untuk nantinya diperbaiki. Pada tahap coding menggunakan PHP Hypertext Preprocessor yaitu bahasa server-side scripting yang menyatu dengan HTML untuk membuat halaman web yang dinamis. Karena merupakan server-side scripting maka sintaks dan perintah-perintah PHP akan dieksekusi di server kemudian hasilnya dikirimkan ke browser dalam format HTML. Manajemen basis data yang digunakan adalah MySQL, yaitu sebuah perangkat lunak system manajemen basis data SQL. Pada tahapan pengujian dilakukan dengan pengujian fungsional aplikasi.

\section{Deployment}

Tahapan Deployment merupakan tahapan akhir berupa implementasi aplikasi kepada pengguna dan pengembangan aplikasi berdasarkan umpan balik yang diberikan agar sistem dapat tetap berjalan dan berkembang sesuai dengan fungsinya.

\section{HASIL DAN PEMBAHASAN}

Dalam pemanfaatan aplikasi pembelajaran untuk anggota remaja masjid terdapat tiga kelompok pengguna yaitu anggota remaja masjid sebagai peserta pembelajaran, pemateri/ pendakwah/ Pembina remaja masjid dan administrator yang fungsinya dijalankan oleh pengurus remaja masjid. Kebutuhan pengguna dapat dilihat pada Tabel 1.

Tabel 1. Kebutuhan pengguna

\begin{tabular}{ll}
\hline Jenis user & \multicolumn{1}{c}{ Kebutuhan/requirements } \\
\hline Anggota & 1. Pengelolaan user \\
remaja & 1.1. Pendaftaran baru \\
masjid & 1.2. Profile \\
& 2. Fungsi Dashboard \\
& 2.1 Materi hari ini \\
& 2.2 Tugas hari ini \\
& 2.3 Arsip materi \\
\hline
\end{tabular}




\begin{tabular}{ll}
\hline Jenis user & \multicolumn{1}{c}{ Kebutuhan/requirements } \\
\hline & 2.4 Arsip tugas \\
& 2.5 Peringkat \\
2.6 Cetak sertifikat \\
pemateri & 1. Setting Materi \\
& 1.1 Kategori materi \\
& 1.2 Materi \\
& 2. Setting Soal \\
& 2.1 Harian \\
& 2.2 Mingguan \\
& 2.3 Bulanan \\
1. Manajemen Master & 1.1 Level \\
1.2 Group & 1.3 Value \\
1.4 Daftar Nilai \\
admin & 2. Fungsi setting website \\
2.1 Tampilan awal \\
2.2 Organisasi \\
3 Penjadwalan \\
3.1 Harian \\
3.2 Mingguan \\
3.3 Bulanan \\
4. Naik level \\
5. Manajemen user \\
5.1 user \\
5.2 admin \\
\hline
\end{tabular}

Gambaran deskripsi dari interaksi yang terjadi antara pengguna dan sistem dapat digambarkan menggunakan diagram usecase. Pada tahap ini dilakukan sebuah pemodelan untuk aktivitas disertai interaksi antara satu atau lebih aktor dengan sistem yang dibuat. Gambar 2 berikut merupakan gambaran usecase dari aplikasi pembelajaran remaja masjid.

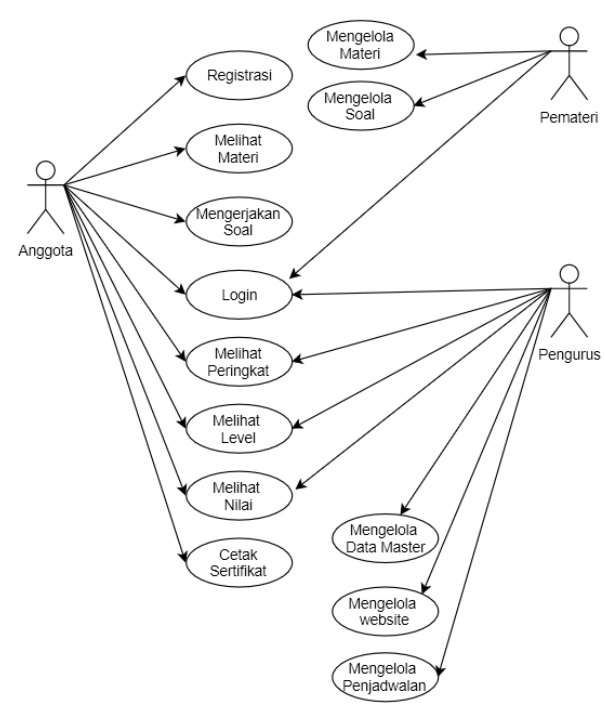

Gambar 2. Usecase Diagram

Dari use case diagram, selanjutnya dibangun sebuah aplikasi pembelajaran bagi remaja masjid dengan tampilan aplikasinya untuk tiga jenis pengguna sebagai berikut.

Pengguna : Anggota remaja masjid

Menu utama bagi anggota adalah registrasi untuk anggota baru dan menu dashboard. Berikut ini adalah menu registrasi untuk anggota baru, terdapat beberapa data yang harus di input antara lain, nama, tempat dan tanggal lahir, jenis kelamin, alamat, email dan password, untuk isian group sudah terisi secara otomatis dari pengaturan yang dilakukan oleh pengurus. Gambar 3 berikut ini adalah menu isian untuk registrasi anggota baru 


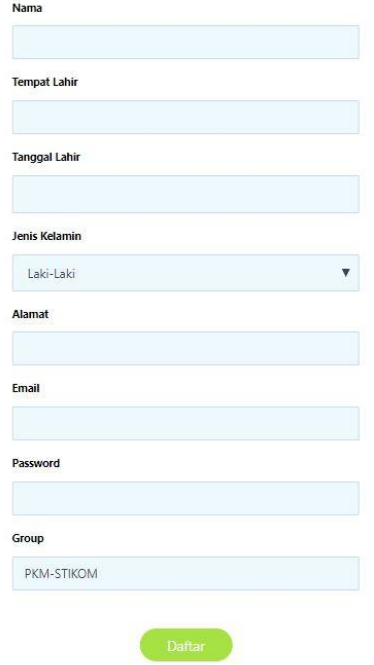

Gambar 3. Menu Registrasi

Aplikasi yang disusun dapat dimanfaatkan untuk anggota remaja masjid mendalami Ilmu Agama Islam, dengan aktifitas harian. Kelompok pengguna anggota remaja masjid dapat memanfaatkan aplikasi dengan menu materi hari ini, tugas (harian, mingguan dan bulanan), melihat nilai berikut dengan peringkatnya, kenaikan level dan mencetak sertifikat sebagai bukti keaktifan dan ketuntasan dalam proses pembelajaran.

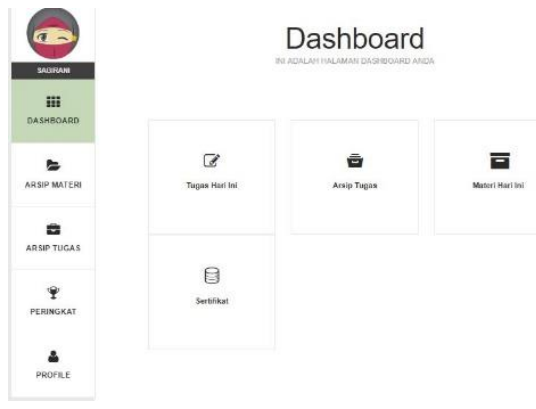

Gambar 4. Menu Dashboard

\section{Pengguna : Pemateri}

Pengguna kelompok pemateri/ pendakwah bertugas untuk menyusun kurikulum, materi dan soal. Materi dan soal akan disampaikan dengan memanfaatkan aplikasi. Materi dapat disampaikan dalam bentuk teks, file dengan format pdf/ doc juga dalam format audio. Sedangkan soal disampaikan untuk periode harian, mingguan maupun bulanan.

Berikut ini adalah kurikulum yang disusun untuk tiap level pembelajaran bagi anggota remaja masjid.

Tabel 2. Daftar Materi

\begin{tabular}{|c|c|c|c|c|}
\hline No & Mat & & Jumlah & Jumlah \\
\hline 1 & $\begin{array}{l}\text { Pengantar } \\
\text { Pengagunga }\end{array}$ & $\begin{array}{l}\text { tentang } \\
\text { Ilmu }\end{array}$ & 1 & 5 \\
\hline 2 & Mendalami & auhid & 1 & 25 \\
\hline 3 & $\begin{array}{l}\text { Mengenal } \\
\text { Sebagai Per }\end{array}$ & $\begin{array}{l}\text { Allāh } \\
\text { ipta }\end{array}$ & 1 & 10 \\
\hline 4 & $\begin{array}{l}\text { Beriman } \\
\text { Kitab-kitab }\end{array}$ & $\begin{array}{l}\text { Kepada } \\
\text { lllah }\end{array}$ & 1 & 25 \\
\hline 5 & Mengenal & alaikat & 1 & 25 \\
\hline 6 & $\begin{array}{l}\text { Beriman } \\
\text { Rasul }\end{array}$ & Kepada & 1 & 7 \\
\hline 7 & $\begin{array}{l}\text { Mengenal I } \\
\text { Dakwah Ra }\end{array}$ & ilullah & 1 & 25 \\
\hline 8 & $\begin{array}{l}\text { Mengenal } \\
\text { Nabi Muha }\end{array}$ & $\begin{array}{l}\text { Sejarah } \\
\text { mad }\end{array}$ & 2 & 50 \\
\hline 9 & $\begin{array}{l}\text { Muhammad } \\
\text { Teladanku }\end{array}$ & & 5 & 120 \\
\hline 10 & $\begin{array}{l}\text { Beriman } \\
\text { Hari Akhir }\end{array}$ & Kepada & 4 & 80 \\
\hline 11 & $\begin{array}{l}\text { Beriman } \\
\text { Taqdir }\end{array}$ & Kepada & 1 & 25 \\
\hline 12 & $\begin{array}{l}\text { Mengenal } \\
\text { Islam }\end{array}$ & Agama & 1 & 8 \\
\hline 13 & Pembatal ke & slaman & 1 & 25 \\
\hline 14 & $\begin{array}{l}\text { Tujuan } \\
\text { Diciptakanr } \\
\text { Manusia }\end{array}$ & & 1 & 25 \\
\hline 15 & $\begin{array}{l}\text { Mengenal } \mathrm{F} \\
\text { Alam }\end{array}$ & nciptaan & 2 & 50 \\
\hline 16 & $\begin{array}{l}\text { Mengenal F } \\
\text { Makhluk }\end{array}$ & nciptaan & 2 & 50 \\
\hline
\end{tabular}

Pengguna : Pengurus (Administrator)

Tugas utama dari pengguna kelompok pengurus remaja masjid atau yang bertindak sebagai administrator adalah mengelola semua data dan informasi untuk dapat disajikan dalam aplikasi dan menjamin semua proses pembelajaran bagi seluruh anggota remaja masjid dapat berjalan dengan 
baik. Tampilan utama bagi pengurus dapat dilihat pada Gambar 5 berikut ini.

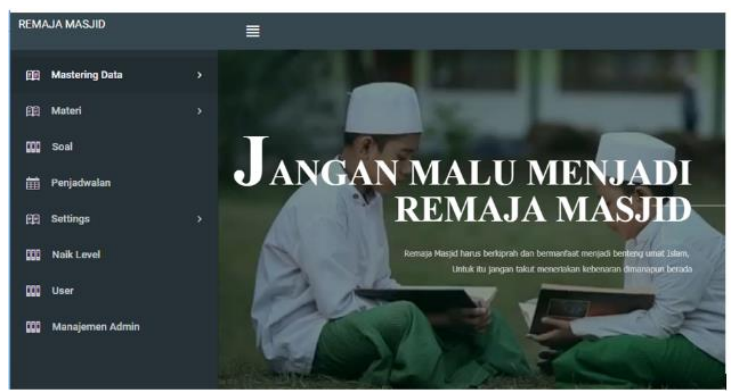

Gambar 5. Menu Administrator

Pengujian Sistem

Pada bagian ini dilaksanakan pengujian dari kebutuhan fungsional sistem. Pengujian ini berfokus pada fungsionalitas sistem dengan validation testing untuk mengetahui apakah fungsionalitas dari sistem yang buat sudah sesuai dengan kebutuhan dari pengguna. Hasil dari validation testing disampaikan pada Tabel 3 berikut ini.

Tabel 3 Hasil Validation Testing

\begin{tabular}{|c|c|c|}
\hline Fungsi & Pengujian & Harapan \\
\hline $\begin{array}{l}\text { Pengguna } \\
\text { (anggota) } \\
\text { dapat } \\
\text { mendaftar } \\
\text { kedalam } \\
\text { sistem }\end{array}$ & $\begin{array}{l}\text { Pengguna } \\
\text { (anggota) } \\
\text { melakukan } \\
\text { pendaftaran } \\
\text { atau registrasi } \\
\text { kedalam } \\
\text { sistem }\end{array}$ & $\begin{array}{l}\text { Sistem dapat } \\
\text { menampilkan } \\
\text { form } \\
\text { pendaftaran } \\
\text { dan entry data } \\
\text { pengguna } \\
\text { kedalam } \\
\text { sistem }\end{array}$ \\
\hline $\begin{array}{l}\text { Sistem dapat } \\
\text { digunakan } \\
\text { untuk } \\
\text { menambah, } \\
\text { edit dan } \\
\text { menghapus } \\
\text { materi }\end{array}$ & $\begin{array}{l}\text { memasukkan } \\
\text { materi dalam } \\
3 \text { format (edit } \\
\text { teks, pdf/doc } \\
\text { dan audio) } \\
\text { kedalam form } \\
\text { materi, } \\
\text { melakukan } \\
\text { perubahan/ } \\
\text { menghapus } \\
\text { materi } \\
\text { dengan } \\
\text { menekan } \\
\text { tombol sesuai }\end{array}$ & $\begin{array}{l}\text { Sistem dapat } \\
\text { menyimpan, } \\
\text { melakukan } \\
\text { perubahan } \\
\text { dan } \\
\text { penghapusan } \\
\text { kategori dan } \\
\text { materi dari } \\
\text { daftar }\end{array}$ \\
\hline $\begin{array}{l}\text { Sistem dapat } \\
\text { digunakan }\end{array}$ & $\begin{array}{l}\text { melakukan } \\
\text { edit/ hapus }\end{array}$ & $\begin{array}{l}\text { Sistem dapat } \\
\text { mengubah }\end{array}$ \\
\hline
\end{tabular}

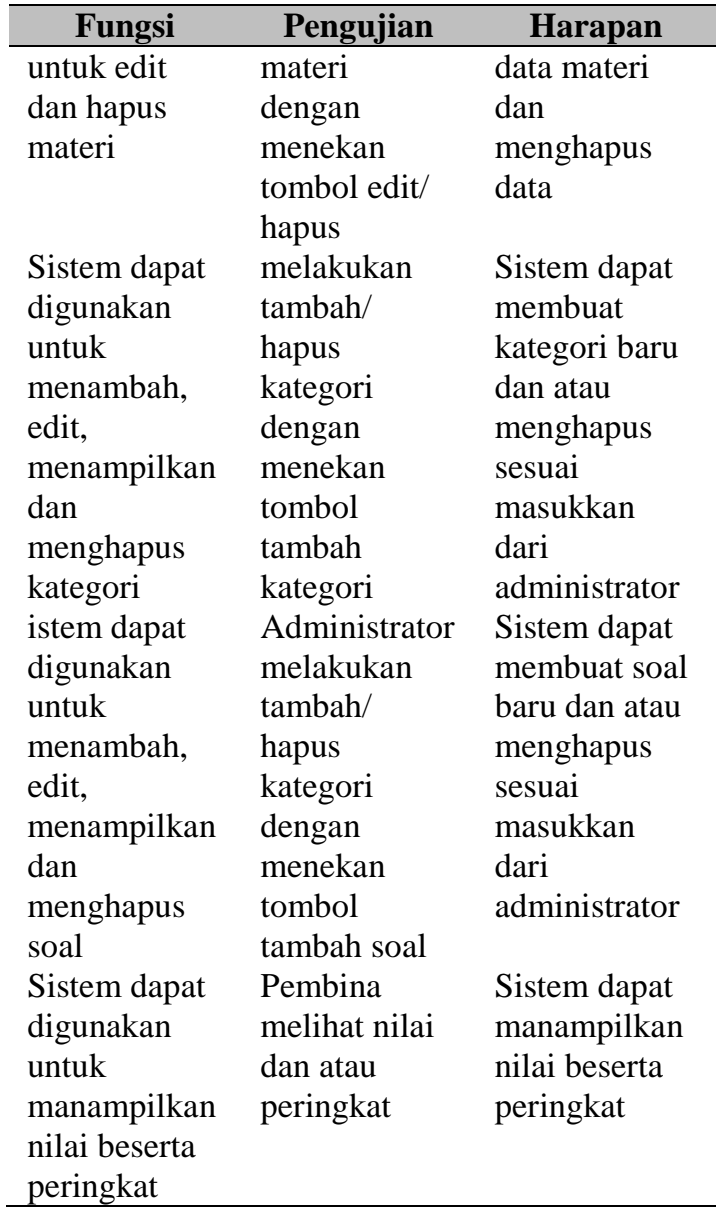

\section{KESIMPULAN}

Pemanfaatan media pembelajaran untuk remaja masjid ini mampu menjadi solusi untuk kemudahan bagi pemateri untuk menyampaikan materi kajian dan dakwah melalui aplikasi berbasis web. Bagi pengurus remaja masjid, aplikasi ini mampu memberikan kesempatan penyebaran materi dan juga lakukan evaluasi terkait ketuntasan proses belajar dalam periode harian, mingguan serta bulanan. Bagi anggota remaja masjid sendiri, aplikasi ini mampu memberikan peningkatan kemampuan/ wawasan dan keilmuan tentang Agama Islam bagi setiap anggota remaja masjid. Aplikasi ini masih memiliki peluang yang luas dalam pengembangannya, terkhusus dalam 
pemanfatan framework Android ataupun IOS.

\section{REFERENSI}

M. Ali dan M. Asrori. (2012). Psikologi Remaja: Perkembangan Peserta Didik. Jakarta: PT. Bumi Aksara.

John W. Santrock. (2007). Remaja, Jilid 2 Edisi Kesebelas. Jakarta: PT. Erlangga

Danny Haryanto dan G. Edwi Nugroho, (2011), Pengantar Sosiologi Dasar. Jakarta: PT. Prestasi Pustakaraya.

Pressman \& Maxim. (2015). Software Engineering, A Practitioner's Approach Eight Edition. New York: McGraw-Hill Education 